\title{
Economics Analysis of Catfish Production in Anambra State, Nigeria
}

\author{
Ume S.I. ${ }^{1}$, Ebeniro .L.A. ${ }^{2}$, Ochiaka C.D. ${ }^{3}$, Uche F.O. ${ }^{4}$ \\ ${ }^{1}$ Department of Agricultural Extension and Management, \\ ${ }^{2,4}$ Department of Fisheries Technology, Federal College of Agriculture, Ishiagu Ebonyi State \\ ${ }^{3}$ Department of Agricultural Economics and Extension, Enugu State University of Science and Technology.
}

\begin{abstract}
The study was on economics of catfish production in Anambra State of Nigeria. Structured questionnaire and oral interview were administered on sixty catfish farmers selected from the state. Percentage response was used to determine the farmers' socioeconomic characteristics and constraints to catfish production. Semi log functional form was used to analyze the effect of farmers' socioeconomic characteristics on their output. The profitability in catfish was determined using gross margin and profit analysis. The result of the socioeconomic characteristics shows that majority of the catfish farmers were male (83.3\%) and of the age bracket of 31-40 (40\%). Most of the catfish farmers were literate (91.7\%) and operated on pond size of $5 \mathrm{~m}^{2}$ (50\%). The socioeconomic determinants to catfish farmers' output were educational level, farming experience and membership of cooperative. The gross margin of $\$ 323,600$ and profit of $\$ 155,100$ were recorded. The gross margin of $\$ 322,600$, profit of $\$ 153,000$, benefit cost ratio of 1.40, expense structure ratio of $0: 48$ and a gross ratio of 0.2123 were recorded. The major constraints to catfish production in the study area were cannibalism, poor access to credit, poor access to extension services, high cost of building material, high cost of feed and poor fish breed and scarcity of fingerling (13.3\%). Recommendations offered included improving farmers' access to improve fingerlings and education through seminars and workshops.
\end{abstract}

Keywords-Analysis, Catfish, Economics, Production.

\section{INTRODUCTION}

Fish is relatively cheap and easily available source of protein dietary supplement for the poor, who cannot afford animal protein and depend mainly on food of low nutritional value. Apart from dietary source, fish is source of fish oil, a raw material for pharmaceutical companies, provision of livestock feeds, and provision of employment for different categories of people in the area of fisheries production, processing, packaging and marketing (Fleuren,
2006). In Nigeria, the current domestic fish production from artesianal water is put at 551,700 metric tones as against the present nation's demand of about 1.5 million metric tones estimated for 2007. The shortfall is said to be bridged by the importation of 680,000 metric tones thus consuming about $\$ 50$ billion in nation's foreign reserve (Odukwe, 2007). It is evident that, the limited supply of fish from marine and fresh water capture fisheries cannot be able to meet the growing world demand for aquatic products (Rana, 2007). FAO (2007) advocated the development and strengthening of aquaculture as important supplement to and substitute for dwindling yield from the wild. Aquaculture according to Odukwe (2007) accounts for close to $50 \%$ of the present global fish consumption. The role of cat fish in aquaculture industry is well acknowledged. For instance, farm-raised catfish is the largest aquaculture industry in the United States. In 2005, the United States of America catfish industry produced 600 million pounds of catfish from 165,000 pond water acres (Rana, 2007). In Nigeria and many other developing countries no available statistics to that effect but literatures show that the fish spices contribute significantly to the natons production

Catfish, particularly Heterobranchus sarus is the specie of choice generally accepted and grown in monoculture by fish farmers in Anambra State, Nigeria (Nwosu, et al, 2001). Catfish are hardy, tolerate dense stocking, and thrive in a wide range of environmental conditions. They are easily spawned under proper conditions, yet will not spawn when placed in the grow-out ponds, which gives the farmer control over the production process (Rana, 2007).

Nevertheless, in Nigeria, aquaculture industry has been plagued with problems and amongst is of low productivity, high mortality, water scarcity, high cost of feed and poor management practices. Catfish, Heterobrachus bidoscarlis has been the specie of choice and generally accepted and grown in monoculture or polyculture by fish farmers in Anambra State (Eyo, 2001). Therefore, to meet the protein demand of people through the provision of fish as source of 
protein for the people, it is necessary to focus on the broad objective of the study so as to boast production to meet both local and international demand. Specifically, the objectives were to describe the socioeconomic characteristics of fish farmers, establish the relationship between farmer's socioeconomic characteristics and their output in catfish production and determine the catfish profitability and constraints to catfish production in the study area.

\section{MATERIALS AND METHODS}

Anambra State is the study area and located between latitude $5^{0} 38^{\prime} \mathrm{N}$ and $6^{0} 47^{\prime} \mathrm{E}$ and longitude $6^{0} 36^{\prime} \mathrm{N}$ and $7^{0} 21^{\prime} \mathrm{E}$.. The state is bounded in the east by Enugu State, in the West by Delta State, in the South by Imo State and in the North by Kogi State. Anambra State has Awka as capital with population figure of 4.184 million people (NPC, 2006).

Multistage random sampling technique was used for the study. Three zones were selected from the four agricultural zones. The selected zones were Onitsha, Awka and Anambra. Four blocks were selected from each of the zones. Five circles were selected from each of the sampled block, making sixty circles. One fish farmer was selected from each circle and interviewed, making a total of sixty farmers. Well structured questionnaire was administered to each of the sixty farmers to collect information on input and output quantities used and their unit prices, farmers' socioeconomic characteristics and other essential information as related to the study. Secondary data were obtained from journals, internets, seminar and other periodicals. Percentage response was used to determine the catfish farmers' socioeconomic characteristics and their constraints to catfish production. Ordinary least square regression method was used to analyze the effect of farmers' socioeconomic characteristics on their output. The model is implicitly stated as:

$\mathrm{Y}=\mathrm{f}\left(\mathrm{X}_{1} \mathrm{X}_{2} \mathrm{X}_{3} \mathrm{X}_{4} \mathrm{X}_{5} \mathrm{X}_{6}+\mathrm{e}\right)$

Where $\mathrm{Y}=$ quantity of catfish produced $(\mathrm{kg}), \mathrm{X}_{1}=$ gender (dummy); $\mathrm{x}_{2}=$ age (yrs), $\mathrm{x}_{3}=$ educational level (yrs), $\mathrm{x}_{4}=$ pond size $\left(\mathrm{m}^{2}\right), \mathrm{X}_{5}=$ membership of cooperative (dummy) $\mathrm{X}_{6}=$ extension contact (Number), $\mathrm{x} 7=$ farming experience (years) e $=$ error term. Four functional forms (linear, double $\log$, semi double $\log$ and exponential functions) of production function were tried and explicitly represented as

Linear function:

$\mathrm{Y}=\mathrm{b}_{0}+\mathrm{b}_{1} \mathrm{x}_{1} \mathrm{~b}_{2} \mathrm{x}_{2}+\mathrm{b}_{3} \mathrm{x}_{3}+\mathrm{b}_{4} \mathrm{x}_{4}+\mathrm{b}_{5} \mathrm{x}_{5}+\mathrm{ei}$ (1)

Double log function (Cobb Douglas):

$\ln (\mathrm{y})=\ln \mathrm{b}_{0}+\mathrm{b}_{1} \ln \mathrm{x}_{1}+\mathrm{b}_{2} \ln \mathrm{x}_{2}+\mathrm{b}_{3} \ln \mathrm{x}_{3}+\mathrm{b}_{4} \ln \mathrm{x}_{4}+\mathrm{b}_{5} \ln \mathrm{x}_{5}+\mathrm{ei}$ (2)

Semi double log function:

$\mathrm{Y}=\ln \mathrm{b}_{0}+\mathrm{b}_{1} \ln \mathrm{x}_{1}+\mathrm{b}_{2} \ln \mathrm{x}_{2}+\mathrm{b}_{3} \ln \mathrm{x}_{3}+\mathrm{b}_{4} \ln \mathrm{x}_{4}+\mathrm{b}_{5} \ln \mathrm{x}_{5}+\mathrm{ei}$ (3)

Exponential function:

$\ln Y=b_{0}+b_{1} x_{1}+b_{2} x_{2}+b_{3} x_{3}+b_{4} x_{4}+b_{5} x_{5}+$ ei............ (4)

The choice of the best functional form was based on the magnitude of the $\mathrm{R}^{2}$ value, the high number of significance, size and signs of the regression coefficients as they conform to a priori expectation.

The profitability ratio and gross margin analysis models were specified as follows:

Benefit Cost Ratio $=$ TR/TC

Gross Ration $=$ DFC/TR

Expenses Structure Ration $(\mathrm{ESR})=\mathrm{FC} / \mathrm{VC}$

Gross Margin $=$ TR - TVC

Profit $(\pi)=\mathrm{GM}-\mathrm{TFC}$.

where: $\mathrm{GM}=$ gross margin, $\mathrm{TR}=$ total revenue, $\mathrm{TVC}=$ total variable cost, TFC = total fixed cost, $($ Ezike, and Adedeji, 2010).

\section{RESULTS AND DISCUSSION}

Table 1 show that the mean age of the farmers was 38 years. This indicates that catfish farmers were youthful and could adopt innovation easily. Most of the farmers (91.7\%) were educated and hence prudent in their resource use (Asiabaka, 2002). Most of the respondents (75\%) did not belong to cooperative organization. This implies that most catfish farmers in the state are not enjoying the benefits of cooperative organization, including training and credit access to members (Ezike, and Adedeji, 2010).

Table.1: Socioeconomics Characteristics of Fish Farmers

\begin{tabular}{lll}
\hline Variables & Frequency & $(\boldsymbol{\%})$ \\
\hline Age (yrs) & & \\
Less than 21 & - & \\
$21-30$ & 8 & 3.3 \\
$31-40$ & 24 & 40
\end{tabular}




\begin{tabular}{lll}
$41-51$ & 20 & 33.3 \\
51 and above & 8 & 13.3 \\
Level of Education & 5 & 8.3 \\
No formal Education & 25 & 41.7 \\
Primary Education & 20 & 33.3 \\
Secondary Education & 10 & 16.7 \\
Tertiary Education & & \\
Membership of Cooperative & 15 & 25 \\
Non-member & 45 & 75 \\
Member & 20 & 33.3 \\
Access to credit & 40 & 66.7 \\
Yes & & \\
NO & & 33.3 \\
Extension Contact & 20 & 66.7 \\
Yes & 40 & \\
No & & \\
\hline
\end{tabular}

\section{Source: Field Survey, 2015}

Furthermore, $66.7 \%$ of the respondents had no access to credit either through formal or informal sector, while $33.3 \%$ had access to credit. The poor access to credit could be attributed to the fact that most farmers in the developing countries are risk averse since agriculture is highly predisposed to hazards which may result in farming failure, consequently unable to pay back the loan. Also, $66.7 \%$ of the catfish farmers interviewed had no contact with extension services. This implies poor extension outreach. Extension services play a very crucial role in creating capacities to improve overall performances of farm production through new technologies

Ordinary least square estimate was used to determine the effect of socioeconomic characteristics in the farmers' output as shown in Table 2. Cobb Douglas log was chosen as lead equation because it had highest $\mathrm{R}^{2}$ of 0.886 and high number of significant variables. The $\mathrm{R}^{2} 0.886$ indicates that $88.6 \%$ variation in the output of catfish farmers in the study area was explained by the independent variables included in the model, the remaining 11.4 were due to error. The coefficient of age of the farmer was negative as expected since according to Unammah (2003) aged farmers are often conservative and not receptive to technology adoption. This situation may not be favourable for agricultural development of the country. Nevertheless, the work of Onyenweaku et al. (2010) had a direct relationship with technology adoption for high production with age of the farmer. They opined that such relationship is stem from accumulated knowledge and experience obtained from years of observations and experimentations with various technologies.

Table.2: Multiple Regression Results

\begin{tabular}{ccccc}
\hline Variable & Linear & Semi Log & Expon. & Double Log \\
\hline Constant & 0.014 & 1.001 & 4.047 & 0.791 \\
& $(4.016)^{* * *}$ & $(7.021)^{* * *}$ & $(6.913)^{* * *}$ & $(3.071)^{* * *}$ \\
Age & 1.007 & 0.777 & 1.766 & 0.001 \\
& $(0.2007)$ & $(0.009)$ & $(0.988)$ & $(0.939)$ \\
Educational & 0.327 & 1.404 & 1.003 & 3.082 \\
Level & $(2.75)^{* *}$ & $(4.707)^{* * *}$ & $(0.437)$ & $(2.44)^{* *}$ \\
Member of & 1.244 & 2.041 & 4.001 & 0.289 \\
Cooperative & $(2.301)^{* *}$ & $(3.491)^{* * *}$ & $(0.473)$ & $(0.2001)$ \\
Extension & 0.792 & 0.299 & 0.217 & 1.275 \\
Contact & $(0.549)$ & $(-2.331)$ & $(2.881)^{* *}$ & $(0.550)$ \\
$R^{2}$ & 0.376 & 0.776 & 0.417 & 0.551 \\
F ratio & 0.524 & 0.621 & 0.337 & 0.451 \\
\hline
\end{tabular}


Source: Field Survey, 2015

The coefficient of education in agreement with apriori expectation was positive and significant at $1 \%$ alpha level. Onwuka et al. (2009) opined that educational status informed the type of job and standard of living one had and this impacted directly on the farmers' production. Ojo and Ajibefuna (2000) observed that high level of education attainment particularly in the developing countries reduces the desire for farming as highly educated farmers probably devoted much of their time on salaried employment instead, particularly in the most developing countries. The membership of cooperative society had direct relationship with the dependent variable and significant at $1 \%$ probability level respectively. The number of socioeconomic associations like cooperatives, age grade and trade union to which a farmer belonged was expected to increase his interaction with his fellow farmers and other entrepreneurs in his environment and such interaction would help them to receive and synthesis new information on economic activities in his locality and even beyond. Okike (2002) observed farmers belonging to cooperatives have access to good quality inputs, information and organized marketing of production. Nevertheless, Ume, et al (2010) had a negative relationship between cooperative membership and high production in their study. They opined that farmers who belong to cooperative societies particularly many of them, may not have enough time to spend in farming because of numerous cooperative activities he/she is involved into, thus low production could ensue.

Extension contact coefficient was negative against apriori expectation and significant at 5\% alpha level. Negative sign of the coefficient of extension contact could be related to extension agents' negligence in discharging their duties and as well as the bottle neck encountered in disseminating extension innovations (Asiabaka, 2002). The coefficient of farming experience was positive and in line with apriori expectation that as years of farming experience of the farmer increases the more likelihood the farmer will be able to surmount many of his $\backslash$ her production and managements constraints for high production and productivity Onyenweku, (2000) reported that aftermath of wealthy years of experience in farming enhances the farmers' capacity of maximizing their farm output and profit at minimal cost.

Table 3 shows that the average total variable cost for rearing 1,000 fish of about $950 \mathrm{~kg}$ for $8-12$ months was $¥ 247,400$, while the total fixed cost was $¥ 119,500$. The total cost amounted to $\$ 386,900$. The average total revenue earned from the sales at $\mathrm{N} 600$ per $\mathrm{kg}$ of $950 \mathrm{~kg}$ of Heterobranchus bidoscarus (catfish) was $\$ 570,000$. The gross margin as shown in table 3 was $\$ 322,600$ and profit of $\$ 153,100$. Profitability estimate result shows that benefit cost ratio (BCR) was 1:40 and as rule of thumb, project with $\mathrm{BCR}$ greater than one $(>1)$, indicates profit. Expense structure ratio (RSR) was 0.48 , which implied that $48 \%$ of the total cost of production is made up of fixed cost component. The lower in the fixed cost will increase the variable input used which will in turn increase total revenue. Gross Ratio (GR) was 0.2123 , which implies that from every $\$ 1.00$ returns to the enterprises, $21.23 \mathrm{k}$ is spent.

Constraints to Catfish Production as shown in Table 4, cannibalism $(91.6 \%)$ was encountered by the respondents and is as result of development of shooters among catfish which prey on young ones, resulting in high losses and poor fish yield (Eyo, 2001).

Majority $(80 \%)$ of the respondents interviewed complained of high cost of feed. Ike et al (2003) reported that high cost and often unavailability of fish feed concentrate make fish farming unproductive. The effect is that farmers stop feeding their fish when the prices of feed is high and resumes only when they can afford the cost. Moreso, Esonu, (1991) opined that poorer resource farmer during period of high cost of feed and resorts to use of poultry mash, which is not in water but so expensive that it takes nearly $70-$ $80 \%$ of the farmers production cost.

Table.4: Constraints to Catfish Production

\begin{tabular}{lll}
\hline Item & Frequency & $\%$ \\
\hline Cannibalism & 55 & 91 \\
Poor access to credit & 52 & 86.7 \\
Poor access to extension sevicee & 50 & 83.3 \\
High cost of feeds & 48 & 80
\end{tabular}




$\begin{array}{lll}\text { Poor fish breed } & 40 & 66.7 \\ \text { High cost of material for pond construction } & 36 & 60\end{array}$

Water scarcity

Total
24

60
40

100

\section{Multiple response}

Source: Field Survey, 2015

More so, $66.7 \%$ of the farmers encounters problem of poor fish feed breeds. Ezuike and Adedeji, (2010) revealed that the performance of this breed is, high uneconomical, as not missing the market target but waste space and finance. This affects adversely profit maximization in fish farming. Poor access to credit was complained by 86.7 of the farmers. The high interest rate, lack of collaterals, short term repayment of loans, ignorance and bank location in urban area could be invoked to explain for the poor access to credit by most farmers interviewed (Ume and Nwaobiala, 2012).

Credit is vital in purchasing productive inputs and in payment of hired labour. In fact the need to increase farmers' access to credit is very mandatory in order to ensure agricultural development (Asiabaka, 2003). In addition, many of the respondents encountered the problem of poor access to information (83.3\%) on improved agricultural innovation. This is occasioned chiefly by high ratio of extension agent - farmers which symbolize agricultural setting in most developing countries, consequently leading to poor extension outreach which is detriment to agricultural development (Ume, and Okoye, 2009). Extension services as opined by Rogers,(2003) is the intermediary for disseminating agricultural innovation and technical assistances to the farmers, for high productivity to ensure.

High cost of building materials ( $60 \%$ ) such as cement, iron rods and planks as consequences of high dollar exchange rate to our local currency and devaluation of the nation's currency as most of these materials are imported.

\section{CONCLUSION AND RECOMMENDATIONS}

The major conclusions derived were: (1) the coefficient of education and membership of cooperatives were the major variables that affected catfish farmer's output; (2) catfish production is a profitable venture in the study area since the total revenue is greater than the total cost of production; and (3) the major constraints to catfish production in the study were cannibalism, high cost of feed, high cost of building material, poor access to extension services, poor fish breed and credit problem. The following recommendations were proffered: scarcity of fingerlings can be solved through organizing workshops and seminars to educate the farmers on fish culture and breeding and where to source it. Framers should be encouraged to form cooperative societies, since cooperative helps in capacity building and easy credit acquisition. Adult education program should be put in place to improve farmers' skills and abilities. .Also there is need improve farmers, access to credit through micro finance banks and commercial banks. .Furthermore, fish should be sorted out according to size at appropriate time and as well adequately fed to avoid cannibalism

\section{REFERENCES}

[1] Asiabaka, C. (2002). Agricultural extension: A handbook for development practitioner, Omoku River State Misinform United States.

[2] Eyo, A.A (2001): Fish Processing Technology in the Tropics. Ilorin University Press. 403pp.

[3] Esonu, W. (1991): Yields of the Africa catfish clarias gariepinus (Burahell) from a low-input homestead concrete pond. Aquaculture 55: 87 - 91.

[4] Ezike, K. N. and Adedeji, P. O. (2010). Economics analysis of catfish production in Akure south L.G.A. of Ondo State, Nig. Proceedings of the $44^{\text {th }}$ Annual conference of Agricultural society of Nigeria AUTECH 2010.

[5] FAO (2007): State of world fisheries and aquaculture. 2006 Food and Agriculture Organization, Rome.

[6] Fleuren, W. (2006). Future of fish farming in Nigeria. a monograph for fish production. Director of Durante Fish Industries Ltd., Ibadan.

[7] Ike, S.E, Onyishi, G.C, Ukwuaba, G.C and Oluason, V.A (2009): Farm evaluation of profitability and farmer's acceptability of Bambara Nut waste as major protein supplement in fish diet in hetrobranchus and tilapia spp polyculture. Proceedings of National 
Farming System Research Network held at Umudike. Pp 127-129

[8] NPC (2006) National Population Commission Estimated Population Figure. Abuja. National Population Commission of Nigeria.

[9] Nwosu, M.C, Nwadukwe, P and Udealor, A (2001). On farm evaluation of fish productivity and acceptability of two polyculture system in Anambra State. Proceedings REFILS work shop held at Umudike, Abia state.

[10] Odukwe, A., (2007) Fish Farming in the Tropics; A Functional Approach, Maxiprints, Awka Nigeria Book Review

[11] Ojo, S. O. and Ajibefun, A. N. (2000). Effect of training on labour productivity and efficiency in oil palm production in Ondo State, Nigeria. Journal of Sustainable Agriculture and Environment, 2(2): 275279.

[12] Okike, I. (2000). Crop livestock interactions and economic efficiency of farmers in the Savannah Zones of Nigeria. Ph.D Thesis, Department of Agricultural Economics, University of Ibadan.

[13] Onyenweaku, C.E. (2000): Policy issues and strategies for agricultural production in Nigeria. A paper presented at the National workshop on enhancing research and development in agricultural root crops towards poverty alleviation and rural development in Nigeria. NRCRI Umudike, 22 - 26 May.

[14] Onyenweaku, C. E., Okoye, B. C. and Okorie, K. C. (2010). Determinants of fertilizer adoption by rice farmers in Bende Local Government Area of Abia State, Nigeria. Nigeria Agricultural Journal, 41(2): 16.

[15] Onwuka, S; Ekwe, K. C and Nwosu, A. C (2009) Comparative analysis of foreign and local consumption in Ikwuano and Umuahia North L.G.A of Abia State. The Nigerian-Agricultural journal 38 (1) $37-41$

[16] Rana, K. (2007): Recent trends in global aquaculture production, 1985 - 2006. Proceedings of the Fisheries Society of Nigeria, Jos, Plateau State.

[17] Rogers, E.M. (2003)Diffusion of innovation. Fifth (Ed) New York Free Press.

[18] Ume, S.I. and Nwaobiala, C.U. Economic efficiency of upland rice farmers across gender in Anambra agricultural zone of Anambra State. .Nigeria Agricultural Journal, 2012; 41(2): 37 - 45.

[19] Ume, S. I. and Okoye, F. U. (2009). Child labour in rice production. A case study of Anambra Agricultural
Zone of Anambra State, Nigeria. Journal of Arts and Social Science Education, 1(1):233-239.

[20] Ume S.I, Okelola, O, Kadurumba C, and Ogwulumba S.I. Tobit analysis of extent of adoption of cocoyam technology among farmer in Nsukka local Government Area of Enugu State, Nigeria. Proceedings of the $44^{\text {th }}$ Annual conference of Agricultural Society of Nigeria (ASN) held at Ladoke Akintola University of Technology Ogbomoso, Oyo Sate, Nigeria held from $18-22^{\text {nd }}$ October IP, 2010; 545- 350.

[21] Unammah, R.P.A. (2003). Agricultural technology generation and transfer strategies for food securities. Proceedings of the $16^{\text {th }}$ Annual zonal Research and Extension, farmers input linkage system (REFILS) Workshop South East/South South zones of Nigeria. $19^{\text {th }}-23$ November. 